Jurnal Manajemen Bisnis

\title{
PENGARUH PERSEPSI DAN PELAYANAN \\ TERHADAP MINAT BELI KONSUMEN DAPUR \\ KWALLI (Studi Pada Konsumen Rumah Makan \\ Dapur Kwalli Kota Tangerang)
}

\section{Yanthi Meitry Gunawan}

Universitas Muhammadiyah Tangerang

\begin{tabular}{|c|c|}
\hline INFO ARTKEL & A B S T R A C T \\
\hline \multirow[t]{3}{*}{$\begin{array}{l}\text { Keyword: } \\
\text { Perceptions, services, buying } \\
\text { Interest }\end{array}$} & $\begin{array}{l}\text { This study aims to determine whether perceptions and services have a positive } \\
\text { and significant effect on consumer buying interest of Dapur Kwalli either } \\
\text { partially or simultaneously. The research method used descriptive analysis } \\
\text { method and multiple regression analysis method. This research uses primary } \\
\text { data and secondary data. Researchers used } 100 \text { respondents as a sample. The } \\
\text { results showed that perceptions and services have a positive and significant } \\
\text { effect on consumer buying interest of Dapur Kwalli partially and simultaneously. }\end{array}$ \\
\hline & INTISARI \\
\hline & $\begin{array}{l}\text { Penelitian ini bertujuan untuk mengetahui apakah persepsi dan layanan } \\
\text { berpengaruh positif dan signifikan terhadap minat beli konsumen Dapur } \\
\text { Kwalli baik secara parsial maupun simultan. Metode penelitian } \\
\text { menggunakan metode analisis deskriptif dan metode analisis menggunakan } \\
\text { regresi berganda. Penelitian ini menggunakan data primer dan data } \\
\text { sekunder. Peneliti menggunakan } 100 \text { responden sebagai sampel. Hasil } \\
\text { penelitian menunjukkan bahwa persepsi dan layanan memiliki pengaruh } \\
\text { positif dan signifikan terhadap minat beli konsumen Dapur Kwalli secara } \\
\text { parsial dan simultan. }\end{array}$ \\
\hline
\end{tabular}




\section{PENDAHULUAN}

\section{Latar Belakang Masalah}

Minat beli merupakan sesuatu yang berhubungan dengan rencana konsumen untuk membeli produk tertentu, serta berapa banyak unit produk yang dibutuhkan pada periode tertentu (Kotler, Bowen \& James Makens, 2002). Minat beli timbul setelah adanya proses evaluasi alternatif dan di dalam proses evaluasi, seseorang akan membuat suatu rangkaian pilihan mengenai produk yang hendak dibeli atas dasar merek maupun minat.

Restoran adalah suatu tempat atau yang diorganisasi secara komersial, yang menyelenggarakan pelayanan dengan baik kepada semua tamunya baik berupa makanan maupun minuman (Marsum, 200I). Tujuan operasi restoran tidak hanya untuk mencari keuntungan, tetapi juga membuat puas para tamu atau konsumen yang datang. Untuk memberikan kepuasan kepada konsumen diperlukan pelayanan yang baik yang pada akhirnya akan membentuk persepsi yang baik pula.

Persepsi pada hakikatnya adalah proses kognitif yang dialami oleh setiap orang di dalam memahami informasi tentang lingkungannya, baik lewat penglihatan, pendengaran, penghayatan, perasaan, dan penciuman. Kunci untuk memahami persepsi adalah terletak pada pengenalan bahwa persepsi itu merupakan suatu penafsiran yang unik terhadap situasi, dan bukannya suatu pencatatan yang benar terhadap situasi.

Kepuasan konsumen dipengaruhi oleh banyak faktor, salah satu diantaranya adalah pelayanan (service). Apabila perusahaan dapat memberikan pelayanan yang baik terhadap konsumen, maka konsumen akan merasa puas dengan pelayanan yang didapatnya, sehingga hal ini akan berpengaruh kepada besar kecilnya permintaan konsumen terhadap barang atau jasa yang dihasilkan.

Rumah makan Dapur Kwalli ini telah berkembang dan tumbuh dengan tingkat profitabilitas yang semakin baik pula. Namun pihak manajemen perlu mempertimbangkan persaingan-persaingan dari restoran atau kafe lain yang sejenis. Kebanyakan para konsumen selalu mempertimbangkan harga dari makanan dan minuman yang dijual serta rasa kenyamanan dan keramahan yang ditawarkan oleh para karyawan restoran tersebut.

\section{Rumusan Masalah}

Berdasarkan latar belakang masalah di atas, maka umusan masalah dalam penelitian ini adalah:

I. Apakah persepsi berpengaruh positif dan signifikan terhadap minat beli.

2. Apakah pelayanan berpengaruh positif dan signifikan terhadap minat beli.

3. Apakah persepsi dan pelayanan secara bersama-sama (simultan) berpengaruh positif dan signifikan terhadap minat beli.

\section{TINJAUAN PUSTAKA}

\section{Persepsi}

Sugihartono, dkk (2007) mengemukakan bahwa persepsi adalah kemampuan otak dalam menerjemahkan stimulus atau proses untuk menerjemahkan stimulus yang masuk ke dalam alat indera manusia.

Menurut Stanton (dalam Setiadi, 2003) "Persepsi dapat didefinisikan sebagai makna yang dipertalikan berdasarkan pangalaman masa lalu, stimuli (rangsangan-rangsangan) yang kita terima melalui panca indera."

Persepsi manusia terdapat perbedaan sudut pandang dalam penginderaan. Ada yang mempersepsikan sesuatu itu baik atau persepsi yang positif maupun persepsi negatif yang akan mempengaruhi tindakan manusia yang tampak atau nyata.

\section{Pelayanan}

Menurut Moenir (2010) pelayanan adalah kegiatan yang dilakukan oleh seseorang atau sekelompok orang dengan landasan faktor materi melalui sistem, prosedur dan metode tertentu dalam rangka usaha memenuhi kepentingan orang lain sesuai dengan haknya. 
Sedangkan Gronroos dalam Tjiptono (2005) menyatakan bahwa pelayanan merupakan proses yang terdiri atas serangkaian aktivitas intangible yang biasa (namun tidak harus selalu) terjadi pada interaksi antara pelanggan dan karyawan, jasa dan sumber daya, fisik atau barang, dan sistem penyedia jasa, yang disediakan sebagai solusi atas masalah pelanggan.

Pelayanan merupakan suatu bentuk sistem, prosedur atau metode tertentu diberikan kepada orang lain, dalam hal ini, kebutuhan pelanggan tersebut dapat terpenuhi sesuai dengan harapan atau keinginan pelanggan dengan tingkat persepsi mereka.

\section{Minat Beli}

Minat beli merupakan kegiatan individu yang secara langsung terlibat dalam mendapatkan dan menggunakan barang dan jasa termasuk didalamnya proses pengambilan keputusan pada persiapan dan penentuan kegiatan kegiatan tersebut (Swastha, 2000).

Minat beli merupakan peryataan mental konsumen yang merefleksikan rencana pembelian sejumlah produk dengan merek tertentu (Durianto, dkk, 2003).

Minat beli diperoleh dari suatu proses belajar dan proses pemikiran yang membentuk suatu persepsi. Minat yang muncul dalam melakukan pembelian menciptakan suatu motivasi yang terus terekam dalam benaknya dan menjadi suatu kegiatan yang sangat kuat yang pada akhirnya ketika seorang konsumen harus memenuhi kebutuhannya akan mengaktualisasi-kan apa yang ada didalam benaknya itu. Dengan demikian, minat beli akan timbul saat dalam proses pengambilan keputusan.

\section{Kerangka Pemikiran}

Minat beli diperoleh dari suatu proses belajar dan proses pemikiran yang yang membentuk suatu persepsi. Minat beli ini menciptakan suatu motivasi yang terus terekam dalam benaknya dan menjadi suatu keinginan yang sangat kuat yang pada akhirnya ketika seorang konsumen harus memenuhi kebutuhannya akan mengaktualisasikan apa yang ada didalam benaknya itu
Berdasarkan uraian di atas, kerangka konseptual penelitian tentang pengaruh persepsi dan pelayanan terhadap minat beli konsumen Dapur Kwalli terlihat pada gambar dibawah ini:

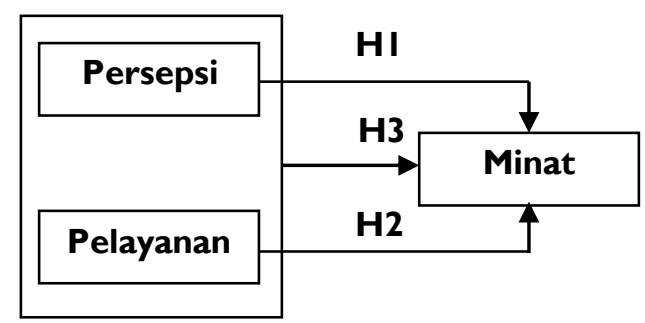

Gambar I. Kerangka Konseptual

\section{Hipotesis}

Berdasarkan latar belakang, rumusan masalah serta kerangka konseptual di atas maka dapatlah diberikan hipotesis dalam penelitian ini yaitu:

HI: Terdapat pengaruh positif dan signifikan antara pelayanan terhadap minat beli.

H2: Terdapat pengaruh positif dan signifikan antara pelayanan terhadap minat beli.

H3: Persepsi dan pelayanan secara bersamasama (simultan) mempengaruhi minat beli.

\section{METODE PENELITIAN}

\section{Variabel Penelitian}

Variabel penelitian adalah hal-hal yang dapat membedakan atau membawa variasi pada nilai (Sekaran, 20I4). Penelitian ini menggunakan dua variabel yaitu variabel independen dan variabel dependen.

I. Variabel dependen (variabel terikat)

Variabel dependen merupakan variabel yang menjadi pusat perhatian peneliti. Hakekat sebuah masalah, mudah terlihat dengan mengenali berbagai variabel dependen yang digunakan dalam sebuah model (Ferdinand, 2006). Dalam penelitian ini yang menjadi variabel dependen adalah minat beli (Y).

2. Variabel independen (variabel bebas)

Variabel independen adalah variabel yang mempengaruhi variabel dependen, baik yang pengaruhnya positif maupun yang pengaruhnya negatif (Ferdinand, 2006). Dalam penelitian ini yang menjadi variabel- 
variabel independen adalah persepsi $\left(X_{1}\right)$ dan pelayanan $\left(\mathrm{X}_{2}\right)$.

\section{Definisi Operasional}

Definisi operasional yang digunakan dalam penelitian ini kemudian diuraikan menjadi indikator empiris dan skala pengukurannya seperti yang dijelaskan pada tabel berikut:

Tabel I. Definisi Operasional Variabel

\begin{tabular}{|c|c|c|c|}
\hline Variabel & $\begin{array}{c}\text { Definisi } \\
\text { Operasional }\end{array}$ & Indikator & $\begin{array}{c}\text { Skala } \\
\text { Pengukuran }\end{array}$ \\
\hline $\begin{array}{l}\text { Persepsi } \\
\text { (XI) }\end{array}$ & $\begin{array}{l}\text { Anggapan } \\
\text { konsumen } \\
\text { terhadap } \\
\text { Dapur Kwalli. }\end{array}$ & $\begin{array}{l}\text { I. Fasilitas di } \\
\text { Rumah } \\
\text { makan ini } \\
\text { lengkap } \\
\text { 2. Karyawan } \\
\text { berpenam } \\
\text { pilan rapi, } \\
\text { bersih dan } \\
\text { menarik } \\
\text { 3. memiliki } \\
\text { peralatan } \\
\text { makanan } \\
\text { yang } \\
\text { lengkap }\end{array}$ & Skal Likert \\
\hline $\begin{array}{l}\text { Pelayanan } \\
(\mathrm{X} 2)\end{array}$ & $\begin{array}{l}\text { Setiap } \\
\text { kegiatan atau } \\
\text { manfaat yang } \\
\text { ditawarkan } \\
\text { suatu pihak } \\
\text { kepada pihak } \\
\text { lain yang pada } \\
\text { dasar nya } \\
\text { tidak } \\
\text { berwujud dan } \\
\text { tidak } \\
\text { mengakibatka } \\
\text { n kepemilikan } \\
\text { apa pun. }\end{array}$ & $\begin{array}{l}\text { 1. Reliability } \\
\text { 2. Responsive } \\
\text { ness } \\
\text { 3. Emphaty }\end{array}$ & Skala Likert \\
\hline $\begin{array}{l}\text { MInat } \\
\text { Beli } \\
\text { (Y) }\end{array}$ & $\begin{array}{l}\text { Sesuatu yang } \\
\text { berhubungan } \\
\text { dengan } \\
\text { rencana } \\
\text { konsumen } \\
\text { untuk } \\
\text { membeli } \\
\text { produk } \\
\text { tertentu serta } \\
\text { berapa banyak } \\
\text { unit produk } \\
\text { yang } \\
\text { diburuhkan } \\
\text { pada periode } \\
\text { tertentu. }\end{array}$ & $\begin{array}{l}\text { I. Kinerja } \\
\text { 2. Pelayanan } \\
\text { 3. Ketahana } \\
n \\
\text { 4. Keandalan } \\
\text { 5. Karakteris } \\
\text { tik } \\
\text { produk } \\
\text { 6. Kesesuaia } \\
\text { n dengan } \\
\text { spesifikasi }\end{array}$ & Skala Likert \\
\hline
\end{tabular}

Sumber: Diolah untuk penelitian ini, 2017

\section{Populasi, Sampel dan Teknik Sampling}

Populasi adalah wilayah generalisasi yang terdiri atas objek atau subjek yang mempunyai kualitas dan karakteristik tertentu yang ditetapkan oleh peneliti untuk dipelajari dan kemudian ditarik kesimpulannya (Sugiyono, 2009). Populasi dalam penelitian ini adalah konsumen Dapur Kwalli di Kota Tangerang.

Sampel adalah bagian dari populasi yang diambil melalui cara-cara tertentu yang juga memiliki karakteristik tertentu, jelas dan lengkap yang dianggap bisa mewakili populasi (Hasan, 2002).

Teknik sampling yang digunakan dalam penelitian ini adalah melalui pendekatan non probability sampling yaitu purposive sampling. Berdasarkan purposive sampling, peneliti memilih sampel purposif secara subjektif dan dalam pemilihan sampel digunakan pertimbangan tertentu yang disesuaikan dengan tujuan atau masalah penelitian yang dikembangkan (Ferdinand 2006). Kriteria sampel pada penelitian ini adalah konsumen yang memenuhi satu dari lima kriteria; pemrakarsa (initiator), pemberi pengaruh (influencer), pengambilan keputusan (decider), pembeli (buyer), pemakai (user).

Penentuan jumlah sampel ditentukan dengan menggunakan beberapa metode antara lain dengan menggunakan rumus sebagai berikut (Widiyanto, 2008). Apabila populasi berukuran besar dan jumlahnya tidak diketahui maka digunakan rumus:

$n=\frac{Z^{2}}{4(\text { Moe })^{2}}=\frac{1,98^{2}}{4(0,1)^{2}}=98,01 \approx 98$ atau

dibulatkan 100

dimana:

$\mathrm{n} \quad$ : jumlah sampel

Z : Tingkat keyakinan yang dibutuhkan dalam penentuan sampel $95 \%$ Pada penentuan ini $Z$ pada $\alpha=0,5$ adalah I,98

Moe : Margin of Error, yaitu tingkat kesalahan maksimal yang dapat ditoreransi, ditentukan sebesar 10\%. 
Dari hasil perhitungan sampel diatas maka jumlah sampel dalam penelitian ini sebanyak 100 responden.

\section{Analisis Regresi Linear Berganda}

Secara umum analisis ini digunakan untuk meneliti pengaruh dari beberapa variabel independen (variabel $X$ ) terhadap variabel dependen (variabel Y) (Ghozali, 2006). Pada regresi berganda variabel independen (variabel $X)$ yang diperhitungkan pengaruhnya terhadap variabel dependen (variabel $\mathrm{Y}$ ), jumlahnya lebih dari satu. Dalam penelitian ini, variabel independen adalah persepsi $\left(X_{1}\right)$ dan pelayanan $\left(X_{2}\right)$ sedangkan variabel dependen adalah minat beli $(Y)$ sehingga persamaan regresi bergandanya adalah:

$Y=a+b_{1} X_{1}+b_{2} X_{2}+e$

Dimana:

Y : Minat Beli

a : Konstanta

$b_{1}, b_{2}$ : Koefisien masing-masing faktor

$\mathrm{X}_{1}$ : Persepsi

$\mathrm{X}_{2}$ : Pelayanan

\section{Pengujian Hipotesis}

Untuk mengetahui pengaruh masingmasing variabel independen pada variabel terikat perlu dilakukan pengujian signifikansi dari masing-masing koefisien regresi yaitu dengan menggunakan Uji t dan uji F.

Uji $t$ didgunakan untuk mengetahui pengaruh variabel independen secara parsial terhadap variabel dependen, apakah pengaruhnya signifikan atau tidak (Priyatno, 2009).

Uji $F$ pada dasarnya menunjukan apakah semua variabel independen atau bebas yang dimasukan dalam model mempunyai pengaruh secara bersama-sama terhadap variabel dependen atau terikat (Priyatno, 2009).

\section{HASIL PENELITIAN}

\section{Analisis Regresi Berganda}

Berikut hasil perhitungan regresi linier berganda antara variabel persepsi $\left(X_{1}\right)$, dan pelayanan $\left(\mathrm{X}_{2}\right)$ terhadap minat beli $(\mathrm{Y})$. Melalui proses perhitungan SPSS 22 dapat diperoleh hasil sebagai berikut:

Tabel 2. Hasil Pengolahan Data Regresi Linier Berganda

\begin{tabular}{|ll|r|r|}
\hline \multirow{2}{*}{ Model } & \multicolumn{2}{|c|}{$\begin{array}{c}\text { Unstandardized } \\
\text { Coefficients }\end{array}$} \\
\cline { 2 - 3 } 1 & \multicolumn{1}{|c|}{ B } & \multicolumn{1}{c|}{ Std. Error } \\
\hline & (Constant) & 5.392 & 1.804 \\
Persepsi & .679 & .167 \\
\cline { 2 - 3 } & Pelayanan & .768 & .140 \\
\hline
\end{tabular}

a. Dependent Variable: MinatBeli

Sehingga dari persamaan rumus regresi linier berganda dapat diperoleh hasil sebagai berikut:

$$
Y=5,392+0,679 X_{1}+0,768 X_{2}
$$

Hasil persamaan regresi berganda tersebut diatas memberikan pengertian bahwa:

a. Nilai konstanta 5,392 mempunyai arti bahwa apabila variabel-variabel bebas yaitu persepi dan pelayanan itu konstan atau tidak berubah maka perubahan minat beli positif.

b. b। (nilai koefisien regresi $X_{1}$ ) 0,679 mempunyai arti bahwa jika persepsi lebih ditingkatkan sedangkan variabel pelayanan tetap (konstan) maka minat beli akan meningkat.

c. $b_{2}$ (nilai koefisien regresi $X_{2}$ ) 0,768 mempunyai arti bahwa jika pelayanan lebih ditingkatkan sedangkan variabel persespi tetap (konstan) maka minat beli akan meningkat.

\section{Analisis Koefisien Determinasi}

Koefisien determinasi digunakan untuk mengetahui seberapa besar variabilitas variabel independen dalam menjelaskan variabel dependen yang ditunjukkan oleh nilai $R$ Square $\left(R^{2}\right)$ yaitu sebesar 0,525; artinya variabilitas variabel persepsi dan pelayanan mampu menjelaskan minat beli konsumen sebesar $52,5 \%$; sedangkan sisanya sebesar $47,5 \%$ dipengaruhi oleh variabilitas variabel lain yang tidak diteliti dalam penelitian ini. Hasil Output SPSS 22 dari koefisien determinasi dapat dilihat pada tabel dibawah ini.

Tabel 3. Koefisien Determinasi

Model Summary

\begin{tabular}{l|c|r|c|c|}
\hline Model & R & R Square & $\begin{array}{c}\text { Adjusted R } \\
\text { Square }\end{array}$ & $\begin{array}{c}\text { Std. Error of the } \\
\text { Estimate }\end{array}$ \\
\hline 1 & $.724^{3}$ & .525 & .515 & 2.15974 \\
\hline
\end{tabular}
a. Predictors: (Constant), Pelayanan, Persepsi




\section{Pengujian Hipotesis}

Pengujian hipotesis dilakukan untuk mengetahui apakah persamaan regresi yang diperoleh dapat dipertanggung jawabkan atau tidak. Bila hasil analisis nanti menunjukkan bahwa persamaan regresi yang bersangkutan adalah signifikan atau dapat dipertanggung jawabkan, maka persamaan regresi tersebut dapat digunakan untuk meramalkan variabel $Y$ dan sekaligus untuk membuktikan hipotesis yang diajukan.

\section{Pengujian Hipotesis Secara Parsial (Uji t}

Uji t digunakan untuk mengetahui pengaruh persepsi $\left(X_{1}\right)$ dan pelayanan $\left(X_{2}\right)$ secara parsial terhadap minat beli $(Y)$.

Tabel 4. Uji Hipotesis Secara Parsial (Uji t) Coefficients $^{\mathrm{a}}$

\begin{tabular}{|c|c|c|c|c|c|}
\hline \multirow[b]{2}{*}{ Model } & \multicolumn{2}{|c|}{$\begin{array}{c}\text { Unstandardized } \\
\text { Coefficients }\end{array}$} & \multirow{2}{*}{$\begin{array}{c}\text { Standardized } \\
\text { Coefficients }\end{array}$} & \multirow[b]{2}{*}{$t$} & \multirow[b]{2}{*}{ Sig. } \\
\hline & $\mathrm{B}$ & Std. Error & & & \\
\hline 1 (Constant) & 5.392 & 1.804 & & 2.989 & .004 \\
\hline Persepsi & .679 & .167 & .348 & 4.079 & .000 \\
\hline Pelayanan & .768 & .140 & .467 & 5.472 & .000 \\
\hline
\end{tabular}

Hasil pengujian hipotesis menunjukkan bahwa nilai $t$ hitung untuk persepsi adalah 4,079 dengan signifikansinya sebesar 0,000 ; sedangkan pada taraf signifikansi sebesar 0,025 dengan degree of freedom (df) sebesar $=97$ diperoleh nilai $\mathrm{t}$ tabel sebesar 1,985 sehingga nilai $t$ hitung $=4,079>$ nilai $t$ tabel $=1,985$. Hal ini menunjukkan bahwa persepsi $\left(X_{1}\right)$ berpengaruh positif dan signifikan terhadap minat beli $(\mathrm{Y})$.

Hasil pengujian hipotesis menunjukkan bahwa nilai $t$ hitung untuk pelayanan adalah 5,472 dengan signifikansinya sebesar 0,000 ; sedangkan pada taraf signifikansi sebesar 0,025 dengan degree of freedom $(\mathrm{df})$ sebesar $=$ 97 diperoleh nilai $t$ tabel sebesar 1,985 sehingga nilai $t$ hitung $=5,472>$ nilai $t$ tabel $=$ 1,985. Hal ini menunjukkan bahwa pelayanan $\left(\mathrm{X}_{2}\right)$ berpengaruh positif dan signifikan terhadap minat beli $(Y)$.

Dengan demikian dapat disimpulkan bahwa persepsi dan pelayanan secara parsial berpengaruh terhadap minat beli konsumen.

2. Pengujian Hipotesis Secara Simultan (uji F)

Uji $F$ digunakan untuk mengetahui pengaruh persepsi $\left(X_{1}\right)$ dan pelayanan $\left(X_{2}\right)$ secara bersama-sama (simultan) terhadap minat beli (Y).

Tabel 5. Uji Hipotesis Secara Simultan (Uji F) ANOVA $^{a}$

\begin{tabular}{|l|c|r|r|r|r|}
\hline \multicolumn{1}{|l|}{ Model } & \multicolumn{1}{c|}{$\begin{array}{c}\text { Sum of } \\
\text { Squares }\end{array}$} & df & \multicolumn{1}{c|}{$\begin{array}{c}\text { Mean } \\
\text { Square }\end{array}$} & F & Sig. \\
\hline 1 Regression & 499.737 & 2 & 249.869 & 53.569 & $.000^{\circ}$ \\
Residual & 452.453 & 97 & 4.664 & & \\
\multicolumn{1}{|c|}{ Total } & 952.190 & 99 & & & \\
\hline
\end{tabular}

a. DependentVariable: MinatBeli

b. Predictors: (Constant), Pelayanan, Persepsi

Hasil perhitungan yang telah dilakukan diperoleh nilai $F$ hitung adalah sebesar 53,569 sedangkan degree of freedom(df) pada angka 2 dan 97 dalam tabel $F$ diperoleh nilai sebesar 3,090 sehingga nilai $F$ hitung sebesar 53,569 $>$ nilai $F$ tabel $=3,090$. Hal ini menunjukkan bahwa terdapat pengaruh signifikan secara bersama-sama antara persepsi $\left(X_{1}\right)$ dan pelayanan $\left(X_{2}\right)$ secara bersama-sama (simultan) terhadap minat beli $(Y)$.

\section{PEMBAHASAN}

\section{Pengaruh positif dan signifikan persepsi terhadap minat beli konsumen}

Hasil penelitian menunjukkan bahwa terdapat pengaruh positif dan signifikan persepsi terhadap minat beli konsumen. Hasil pengujian hipotesis menunjukkan bahwa nilai $\mathrm{t}$ hitung untuk persepsi adalah 4,079 dengan signifikansinya sebesar 0,000 ; sedangkan pada taraf signifikansi sebesar 0,025 dengan $\mathrm{df}$ sebesar $=97$ diperoleh nilai $\mathrm{t}$ tabel sebesar 1,985 sehingga nilai $t$ hitung $=4,079>$ nilai $t$ tabel $=1,985$. Dengan demikian menunjukkan bahwa terdapat pengaruh positif dan signifikan antara persepsi $\left(X_{I}\right)$ terhadap minat beli $(Y)$.

Hipotesis pertama $(\mathrm{HI})$ menyebutkan bahwa terdapat pengaruh positif dan signifikan persepsi terhadap minat beli konsumen, berhasil didukung oleh data atau dengan kata lain hipotesis diterima. Semakin tinggi tingkat persepsi yang dimiliki konsumen, maka minat beli konsumen akan semakin tinggi.

\section{Pengaruh positif dan signifikan pelayanan terhadap minat beli}

Hasil penelitian menunjukkan bahwa terdapat pengaruh positif dan signifikan 
pelayanan terhadap minat beli. Hasil pengujian hipotesis menunjukkan bahwa nilai $t$ hitung untuk pelayanan adalah 5,472 dengan signifikansinya sebesar 0,000; sedangkan pada taraf signifikansi sebesar 0,025 dengan df sebesar $=97$ diperoleh nilai $\mathrm{t}$ tabel sebesar $\mathrm{I}, 985$ sehingga nilai $\mathrm{t}$ hitung $=5,472>$ nilai $\mathrm{t}$ tabel $=1,985$. Dengan demikian menunjukkan bahwa terdapat pengaruh positif dan signifikan antara pelayanan $\left(\mathrm{X}_{2}\right)$ terhadap minat beli $(\mathrm{Y})$.

Hipotesis pertama $(\mathrm{H} 2)$ menyebutkan bahwa terdapat pengaruh positif dan signifikan pelayanan terhadap minat beli, berhasil didukung oleh data atau dengan kata lain hipotesis diterima. Semakin tinggi tingkat pelayanan yang diberikan kepada konsumen, maka minat beli konsumen akan semakin tinggi.

\section{Pengaruh persepsi dan pelayanan secara bersama-sama (simultan) terhadap minat beli konsumen}

Berdasarkan hasil dari analisis pengaruh persepsi dan pelayanan terhadap minat beli konsumen melalui uji $\mathrm{F}$ dapat diketahui bahwa variabel-variabel bebas (persepsi dan pelayanan) mempunyai pengaruh secara bersama-sama terhadap variabel terikatnya (minat beli). Hal ini dapat ditunjukkan melalui hasil uji $\mathrm{F}$ dengan nilai $F$ hitung sebesar 53,569 dengan P-value sebesar 0,000 . Nilai $F$ hitung yang diperoleh menunjukkan nilai yang lebih besar dari $F$ tabel ( $\mathrm{F}$ hitung $>\mathrm{F}$ tabel; $17,550>3,090$ ) dan nilai signifikan yang lebih kecil dari $5 \%(0,000<0,05)$, dapat disimpulkan bahwa variabel-variabel bebas dalam penelitian ini (persepsi dan pelayanan) secara bersama-sama mempengaruhi variabel terikatnya (minat beli).

Hipotesis tiga $(\mathrm{H} 3)$ menyebutkan bahwa terdapat pengaruh positif dan signifikan persepsi dan pelayanan secara bersama-sama (simultan) terhadap minat beli berhasil didukung oleh data atau dengan kata lain hipotesis diterima. Minat beli akan semakin meningkat bila dikaitkan dengan semakin tingginya persepsi konsumen dan pelayanan yang semakin tinggi dari rumah makan Dapur Kwalli.

\section{PENUTUP}

\section{Kesimpulan}

Berdasarkan penelitian yang telah dilakukan maka dapat diperoleh kesimpulan sebagai berikut:

I. Terdapat pengaruh positif dan signifikan antara persepsi dan pelayanan secara bersama-sama (simultan) terhadap minat beli.

2. Hasil uji signifikansi terhadap nilai koefisien regresi secara parsial variabel persepsi dan pelayanan berpengaruh signifikan terhadap kinerja karyawan

3. Berdasarkan hasil uji $R^{2}$ variabel bebas (persepsi dan pelayanan) memberikan kontribusi perubahan dalam variabel terikat (minat beli) sebesar $52,5 \%$.

\section{Saran}

Berdasarkan hasil penelitian maka dapat diberikan saran-saran sebagai berikut:

I. Bagi Dapur Kwalli, hendaknya memperhatikan faktor persepsi konsumen dan pelayanan kepada konsumen karena faktor tersebut terbukti memiliki pengaruh terhadap minat beli konsumen.

2. Penelitian akan lebih baik apabila tidak hanya menggunakan kuesioner saja tetapi dilengkapi dengan teknik wawancara atau metode lain agar bias mendapatkan data yang lebih valid dan sesuai dengan kenyataan yang sebenarnya.

\section{DAFTAR PUSTAKA}

Durianto, Darmadi, dkk. 2003, Invasi Pasar dengan Iklan yang Efektif. Jakarta: Gramedia.

Ferdinand, Augusty. 20II, Metode Penelitian Manajemen Pedoman Penelitian untuk Penulisan Skripsi, Tesis, dan Disertasi Ilmu Manajemen, Edisi 3. AGF Books. Fakultas Ekonomika dan Bisnis Universitas Diponegoro. Semarang.

Ghozali, Imam. 2006, Aplikasi Analisis Multivariate dengan Program SPSS. Semarang: Badan Penerbit UNDIP.

Hasan, lqbal. 2002, Pokok-pokok Materi Metode Penelitian dan Aplikasinya. Jakarta: Ghalia Indonesia. 
Kotler, Bowen \& James Makens. 2002,

Pemasaran Perhotelan dan

Kepariwisataan, Edisi kedua. Jakarta:

Prenhallindo.

Marsum. 200I, Restoran dan Segala

Permasalahannya. Yogyakarta:

Penerbit Andi.

Moenir, A.S. 20I0, Manajemen Pelayanan Umum Di Indonesia. Jakarta: Bumi Aksara.

Priyatno, Duwi. 2009, SPSS untuk Analisis Korelasi, Regresi, dan Multivariate. Yogyakarta: Gava Media.

Sekaran, Uma. 20I4, Metodologi Penelitian untuk Bisnis (Research Methods for Business). Buku I Edisi 4. Salemba Empat. Jakarta.

Setiadi, Nugroho J. 2003, Perilaku Konsumen: Konsep dan Implikasi untuk Strategi dan Penelitian Pemasaran. Kencana. Jakarta.

Stanton, William J. 20I2, Prinsip Pemasaran. Alih bahasa: Yohanes Lamarto. Penerbit Erlangga. Jakarta

Sugihartono, dkk. 2007, Psikologi Pendidikan. UNY Press. Yogyakarta.

Sugiyono. 2009, Metode Penelitian Bisnis. Alfabeta. Bandung.

Swastha, Basu. 2000, Pengantar Bisnis Modern, Pengantar Ekonomi Perusahaan Modern. Jakarta: Liberty.

Tjiptono, Fandy. 2005, Pemasaran Jasa. Malang: Bayumedia Publishing.

Widiyanto, Ibnu. 2008, Pointers Metodologi Penelitian. Semarang: CV Dikalia. 